Original Research Paper

\title{
Electrophoretic Identification of Casein in Various Types of Milk
}

\author{
${ }^{1}$ Makhpal Yelubaevna Yelubaeva, ${ }^{1}$ Batyrkhan Azimkhanovich Buralkhiev, ${ }^{1}$ Assiya Demeukhanovna \\ Serikbayeva, ${ }^{2}$ Mirash Hudretovna Narmuratova and ${ }^{3}$ Shynar Yırmkızy Kenenbay \\ ${ }^{1}$ The Kazakh National Agrarian University, 8, Abay Avenue, Almaty, Kazakhstan, 050008, Kazakhstan \\ ${ }^{2}$ The Al-Farabi Kazakh National University, 71, al-Farabi Ave. Almaty, Kazakhstan, 050040, Kazakhstan \\ ${ }^{3}$ The Almaty Technological University, 100, Tole bi, Almaty, Kazakhstan, 050012, Kazakhstan
}

Article history

Received: 08-08-2017

Revised: 13-09-2017

Accepted: 29-11-2017

Corresponding Author:

Makhpal Yelubaevna

Yelubaeva

The Kazakh National Agrarian

University, 8, Abay Avenue,

Almaty, Kazakhstan, 050008,

Kazakhstan

E-mail: yelubaeva@yandex.ru

\begin{abstract}
Casein proteins of camel milk were obtained from skimmed milk by sedimentation $(\mathrm{pH} 4.6)$ at $24^{\circ} \mathrm{C}$. To sediment proteins from mare milk, $\mathrm{pH}$ was increased to 4.6 and milk was centrifuged at $45,000 \mathrm{rpm}$ for 30 minutes at $4{ }^{\circ} \mathrm{C}$. The supernatant obtained after centrifugation was heated up to $30^{\circ} \mathrm{C}$ for further fractionation of whey proteins. The sedimented casein from camel and mare milk was cleaned with chromatography. Casein fractions were analyzed with the use of electrophoresis based on SDS-Na polyacrylamide. This analysis showed the presence of $\alpha-, \beta-$ and $\kappa$-caseins, as well as fractions of whey proteins, such as $\alpha$ lactalbumin and $\beta$-lactoglobulin in various types of milk and fermented products. Comparative study by the content of protein component of the casein complex in camel milk showed the following: as-casein 31.5\%, $\beta$-casein $64.5 \%$, $\kappa$-casein $4 \%$, in cow milk $40.12 \%, 24.28 \%, 27.93 \%$, respectively and $\gamma$-casein amounts to $7.67 \%$.
\end{abstract}

Keywords: Proteins, Casein, Whey Proteins, Camel Milk, Mare Milk

\section{Introduction}

Today, the demand grows worldwide for high-quality natural dairy products not only from cow milk, but from milk of various farm animals. With that, the issue of creating a range of products with high content of protein, vitamins and minerals is urgent. The solution to this problem may be found in providing the population with high-quality dairy products made of dairy raw materials - from camel and mare milk, which are well-known to the population of Kazakhstan, but very little used traditionally in dairy food industry. Dairy products companies have the highest demand for one of milk protein components - casein and for its specific weight, dispersion and fractional composition. Despite the fact that, compared to cow milk, camel milk contains a higher mass fraction of fat and protein, its processing into fermented dairy products is accompanied by significant loss of these components of the clump with whey during thermal treatment. Identifying the reason of this loss of components of camel milk whey clump would allow developing and applying biotechnological methods aimed at reducing the losses and, consequently, increasing the yield per unit of raw milk material. This, first and foremost, would promote production of a range of products from camel milk at large milk processing companies and at farming enterprises of Kazakhstan. Besides, solving this problem would expand the circle of consumers of dairy products with high content of protein, fat, vitamins and minerals based on nontraditional types of milk.

Due to the fact that production yield and loss of its component mainly depend on the content of protein in the milk, including concentration of casein, we assessed the physico-chemical composition and determined the form of nitrogen (protein) in camel milk, mare milk, kumis (fermented mare milk) and shubat (fermented camel milk), as well as concentration and size of casein micelles.

Information about the structure and functions of main milk proteins is now quite comprehensive, although their transformations and possible nutritional and nutraceutical functions are still being intensively studied. Surprisingly, in case of mare milk and camel milk caseins, the situation is quite opposite, which is known even less than in case of cow milk casein. Recently, many papers have been studying the effect of milk and dairy products, especially fermented products, on the consumers and on the benefits to their health. In this area, mare milk and kumis, camel milk and shubat look
Science

Publications 
very promising. Based on their composition in terms of proteins, lactose, vitamins and macro- and micronutrients, mare and camel milk are more similar to human breast milk (Konuspayeva et al., 2009; Faye et al., 2010).

Casein proteins were studied as whey proteins of mare milk. However, casein proteins of camel and mare milk still remain relatively poorly studied; their study is limited to determining the total content of casein, amino acid composition, or electrophoretic structures of all casein fractions (Salamon et al., 2009; Salmen et al., 2012).

In fresh milk, casein is present in the form of micelles built of casein complexes.

Most researchers have a common opinion about the higher caloric value of camel milk, as compared to the similar indicator of cow milk and absence of allergens in its composition (El-Agamy et al., 2009). They explain the absence of allergic reaction in humans in case of drinking camel milk by the fact that it mainly contains $\alpha$ - lactalbumin protein fraction, while cow milk mainly contains $\beta$-lactoglobulin protein fraction (Kappeler and Puhan, 1998; Mohamed, 1990; Farah, 1993a). After casein sedimentation from milk skimmed by acid, whey contains $0.5-0.8 \%$ of proteins (15-20\% of total protein), which are called whey proteins. The main ones are $\alpha$-lactalbumin, $\beta$-lactoglobulin, blood whey albumin, immunoglobulins and components of the proteose-peptone fraction. They are very important physiologically, being carriers of the immune properties that are transmitted to the newborn with mother's milk. Besides, whey contains lactoferrin, enzymes and other minor components (Farah and Ruegg, 1989; Farah, 1986). Plasma proteins dissolve at the $\mathrm{pH}$ of 4.6 . Classification of individual whey proteins is based on the primary sequence of amino acids in their polypeptide chains, although gel-based electrophoresis might be also used to characterize and identify; individual serum proteins (Farah, 1993a; Hill, 1989).

As one can see from the growing basic knowledge about dairy cattle and its impact on the dairy industry in developed countries, further studying of proteins of camel and mare milk may also have positive effect on transformation and more rational use of these important food products in Kazakhstan and other Central Asian countries (Konuspayeva et al., 2009; Faye et al., 2010). In addition, it is traditionally believed that fresh and fermented camel and mare milk has several nutritional and medicinal properties, which are to be verified during research. Therefore, this study was aimed at detecting and studying protein fractions of casein from camel and mare milk from Kazakhstan.

\section{Materials and Methods}

\section{Preparation of Samples}

The study was aimed at studying raw whole camel and mare milk, as well as shubat and kumis. After collection, milk and fermented products were frozen at $20^{\circ} \mathrm{C}$ until further processing. Samples of milk and fermented products were taken from the same species of camels and mares.

The molecular mass distribution of proteins was assessed with the use of protein electrophoresis by the Laemmli method (Laemmli, 1970). Proteins were fractioned in denaturating polyacrylamide gel (separating $12 \%$ and focusing $4 \%$ ) with $0.1 \%$ of SDS$\mathrm{Na}$. Electrophoresis was performed at a single buffer with addition of $0.1 \%$ SDS-Na at $15 \mathrm{~mA}$. The gel was dyed with $0.2 \%$ of Kumassi R-250 dye (prepared in glacial acetic acid) and then was rinsed three times with distilled water.

Before electrophoresis, milk and fermented products (kumis and shubat) were incubated in the presence of sodium dodecyl sulfate, which forms negatively charged complexes with milk proteins. Besides, processing milk proteins with mercaptan, which restores disulfide bonds, results in the complete destruction of protein complexes. Protein mobility in the polyacrylamide gel may be influenced by its molecular weight (Laemmli, 1970).

The gel was calibrated with the use of protein markers that contained 7 highly purified recombinant proteins with the molecular weight of 10 to $100 \mathrm{kDa}$, which, after electrophoresis in polyacrylamide gel and fixation with dye, form discrete bands.

The obtained data were subjected to standard statistical processing on a personal computer with the use of software products.

\section{Discussion and Results}

Electrophoresis in PAGE with SDS-Na made it possible to clearly identify the heterogeneity of casein and to detect fluctuations in the fractions of casein in the examined samples of milk and fermented foods (shubat, kumis).

For the purpose of quantitative determination of casein fractions on the image of gel by means of extrapolation, their corresponding bands were determined (Fig. 1).

For this purpose, the length of the path of Rf marker proteins was measured with a ruler and the calibration curve was built, representing the dependence of the length of marker proteins' path on the logarithm of their molecular weight $(\mathrm{Rf}=\mathrm{f}(\mathrm{lgM} . \mathrm{m}))$. After that, knowing the molecular weight of the studied fractions, the length of their Rf path was found by the calibration curve. Knowing the length of the path of studied protein fractions, the required bands were found on the gel. Quantification of casein was performed with the use of ScionImage computer program, which performed digital processing of bands images.

The results of electrophoresis showed that the number of casein protein fractions in camel milk and 
shubat, as well as in cow milk, was higher than that of casein proteins fractions in mare milk and kumis. Development of the methods provided the opportunity to separate fractions of whey proteins, such as $\alpha$ lactalbumin and $\beta$-lactoglobulin.

Performing denaturating electrophoresis in polyacrylamide gel with mercaptan allowed separating the casein fraction into $\alpha$ - , $\beta$ - and $\kappa$-caseins. Besides, fractions of $\alpha$-lactalbumin and $\beta$-lactoglobulin were separated (Fig. 2).
All fractions of casein contain phosphorus, unlike whey proteins. The group of $\alpha$ - caseins has the highest electrophoretic mobility of all casein fractions.

Studying the fractional composition of caseins and whey proteins from various types of milk showed insignificant changes in the content of all proteins' fractions after fermentation. This is due to the fact that camel and mare milk is not subjected to heat treatment. However, partial separation occurs during fermentation.

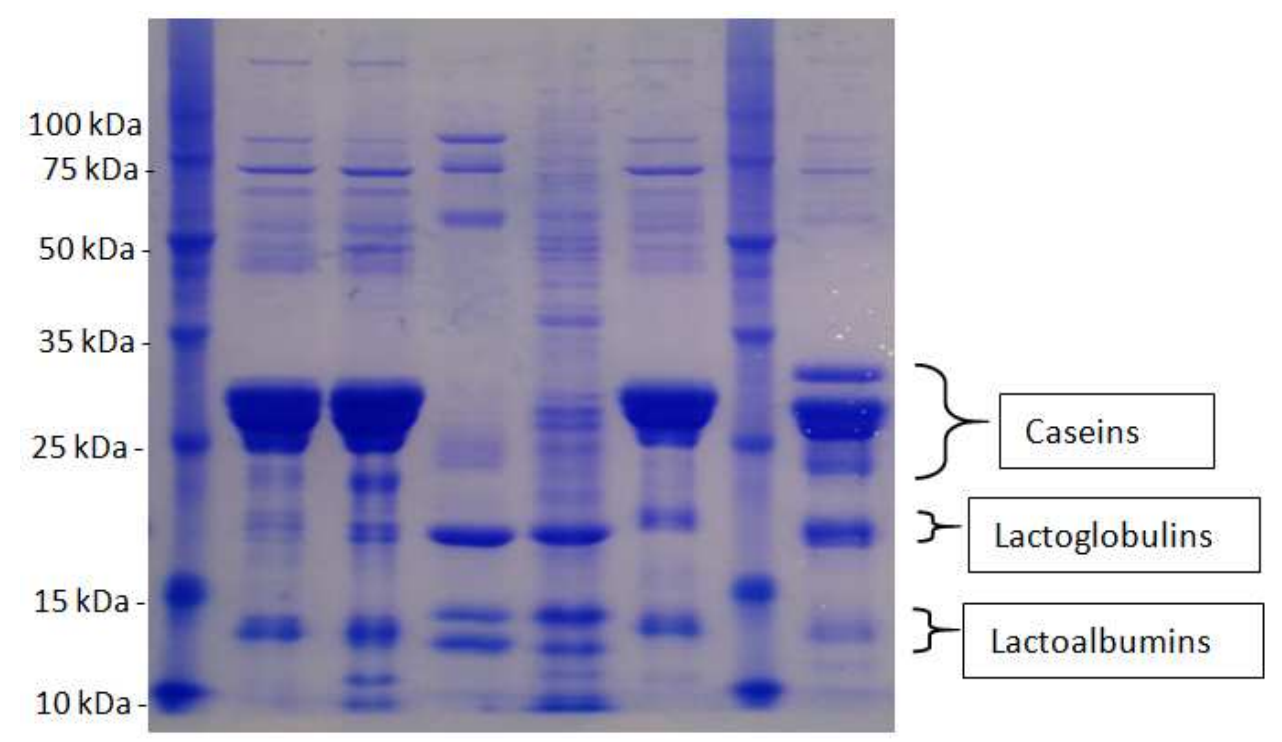

Fig. 1:Electrophoretic separation of protein fractions from various types of milk and fermented products (kumis and shubat): Lines: 1, 7 protein marker, 2-camel milk, 3-fermented camel milk, 4-mare milk, 5-fermented mare milk, 6- dried camel milk, 8 - cow milk

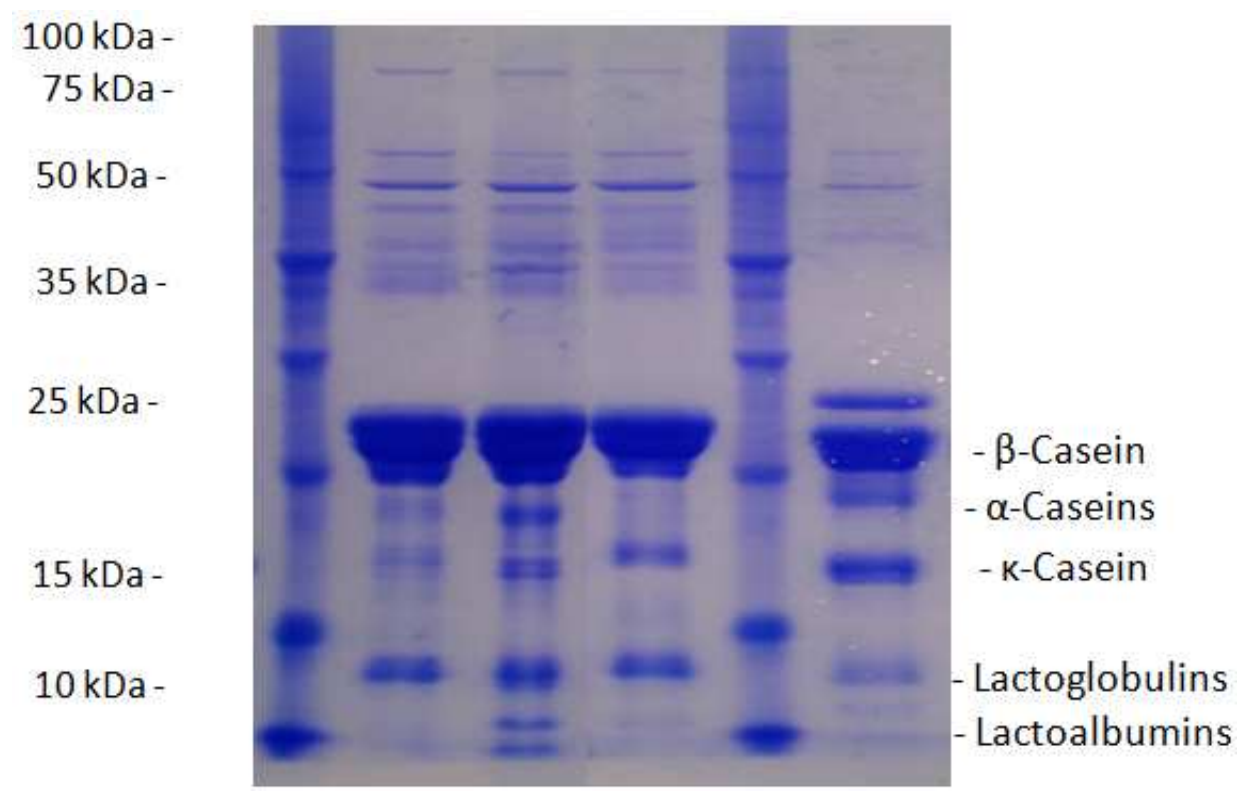

Fig. 2:Electrophoretic separation of camel milk and shubat casein fractions: Lines: 1, 5 - protein marker, 2-camel milk, 3fermented camel milk, 4- dried camel milk, 6 - cow milk 
The results of electrophoresis showed that the relative migration of casein bands was not identical. In caseins of camel milk, the relative migration of $\alpha s-, \beta-$ and $\kappa$ casein was slower than in casein of cow milk. The same trend was observed in the studies of other authors (Metwalli and Al-Saleh, 2010; El-Agamy et al., 2009). This indicated the difference in the molecular weight of casein in camel and cow milk. The molecular weights of $\alpha$-, $\beta$ - and $\kappa$-caseins in camel caseins were estimated at $25,23.8$ and $22.4 \mathrm{kDa}$, respectively, compared to 25.3 , 22 and 20.5 for cow milk caseins in the same order. The obtained results were close to the results obtained by ElAgamy et al. (2009) and Kappeler and Puhan (1998), which were 28 and $22.9 \mathrm{kDa}$ for $\alpha$ - and $\kappa$-casein, respectively, compared to 27.6 and 22.4 in these studies (El-Agamy et al., 2009; Kappeler and Puhan, 1998). However, the molecular weight of $\beta$-casein in camel milk was lower than that stated by El-Agamy et al. (2009) who found the molecular weight for $\beta$-casein in camel milk to be $25 \mathrm{kDa}$ (El-Agamy et al., 2009).

After electrophoretic separation of casein protein fractions, the proportion of individual fractions of casein proteins was found. The relative content of protein component of the casein complex in camel milk was the following: as-casein $31.5 \%$, $\beta$-casein $64.5 \%$, $\kappa$-casein $4 \%$, in cow milk $40.12 \%, 24.28 \%, 27.93 \%$, respectively and $\gamma$-casein amounts to $7.67 \%$.

Studying the amino acid composition of $\beta$-casein in camel and cow milk showed that the content of essential amino acids like isoleucine (responsible for synthesis of hemoglobin), leucine (helps restore collagenic protein), lysine (essential for normal bone formation and growth), threonine (helps maintain normal metabolism of protein in the organism) was higher in the $\beta$-casein fraction of cow milk than in camel milk. In its turn, camel milk was rich in other essential amino acids, such as histidine (responsible for formation of red and white blood cells), phenylalanine (CNS stimulant), tryptophan (synthesis of serotonin in the brain), valine (stimulates tissues and muscles).

Studying the total concentration of the casein complex and whey proteins in cow and camel milk showed that casein of camel milk was $73.3 \%$ of the total protein content.

Studying the casein complex by electrophoresis on PAGE showed that proteins of camel milk had significantly lower electrophoretic mobility. The electrophoretic sample provided three main factions, which were indicated according to their mobility by characters $\mathrm{B}, \mathrm{A}$ and $\mathrm{C}$. These three fractions were classified as follows: $\mathrm{B}$ corresponds to $\beta$ - casein, $\mathrm{A}-$ to $\alpha$ - casein and $\mathrm{C}$ - to genetic variants of $\alpha \mathrm{s}-$ casein in cow and camel milk.

\section{Conclusion}

Relative migration of casein fractions in camel and mare milk, as well as in their fermented product was not identical. The relative migration of $\alpha$-, $\beta$ - and $\kappa$-casein in camel casein was slower than that in cow casein. The molecular weights of $\alpha-, \beta$ - and $\kappa$-casein in camel caseins were between 25 and $15 \mathrm{kDa}$, respectively. The content of protein component of the casein complex in camel milk was the following: $\alpha$ s - casein was $50.78 \%$, $\beta$-casein was $17.85 \%$, $\kappa$-casein was $16 \%, \gamma$-casein was $15.37 \%$; the content in cow milk was $40.12 \%, 24.28 \%$, $27.93 \%$ and $7.67 \%$, respectively. To understand the structure of casein proteins in camel and mare milk, more research is needed.

After the analysis of the protein profile of milk products from camel milk using various microbiological ferments, it can be noted that in dairy products made of camel milk, $\beta$-lactoglobulin is not identified, which once again confirms the information about its absence in camel milk.

Currently, the products obtained from camel milk are positioned in the Kazakhstan market as therapeutic, hypoallergic, dietary, but not as products of mass consumption. However, the potential of camel milk as a raw material is quite high, due to its unique chemical structure, namely, due to the absence of allergen $\beta$ lactoglobulin in the milk composition. With the increase in the production volumes of milk of this kind and fermented milk products made from it, it will be able to compete with fermented milk products made from cow milk.

\section{Author's Contributions}

All authors equally participated in all experiments, coordinated the data.

\section{Ethics}

This article is original and contains unpublished material. The corresponding author confirms that all of the other authors have read and approved the manuscript and there are no ethical issues involved.

\section{References}

Konuspayeva, G., B. Faye and G. Loiseau, 2009. The composition of camel milk: A meta-analysis of the literature data. J. Food Composition Anal., 22: 95-101.

El-Agamy, E.I., M.A. Nawar, S.M. Shamsia, S. Awad and G. Haenlein, 2009. Are camel milk proteins convenient to the nutrition of cow milk allergic children. Sma. Rum. Res., 82: 1-6.

Farah, Z. and M.W. Ruegg, 1989. The size distribution of casein micelles in camel milk. Food Microstruct, 8: 221-233. 
Farah, Z., 1986. Effect of heat treatment on whey proteins of camel milk. Milchwissenschaft, 41: 763-765.

Farah, Z., 1993. Composition and characteristics of camel milk. J. Dairy. Res., 60: 603-626.

Faye, B., G. Konuspayeva and G. Loisean, 2010. Variability of urea concentration in camel milk in Kazakhstan. Dairy Sci. Technol., 90: 707-713.

Hill, A.R., 1989. The B lactoglobulin- K- casein complex. Can Inst Food Sci Technol J., 22: 120-123.

Kappeler, S., Z. Farah and Z. Puhan, 1998. Sequence analysis of Camelus dromedaries milk caseins. J. Dairy Res., 65: 209-222.

Laemmli, U.K., 1970. Cleavage of structural proteins during the assembly of the head of bacteriophage T4. Nature, 227: 680-685.

Metwalli, A.M. and A.A. Al-Saleh, 2010. Susceptibility of camel, buffalo and cow milk caseins to proteolysis by different proteolytic enzymes. J. King Saud Univ. Agric. Sci., 22: 59-69.
Mohamed, M.A., 1990. Camel milk: Chemical composition, characterization of casein and preliminary trial of cheese-making properties. Dissertation AbstractsInt.

Salamon, R., J. Csapo, S. Salamon and Z. Csapo-Kiss, 2009. Composition of mare's colostrum and milk. I. Fat content, fatty acid composition and vitamin contents. Acta Univ. Sapientiae, Alimentaria, 2: 119-131.

Salmen, S.H., H.M. Abu-Tarboush, A.A. Al-Saleh and A.A. Metwalli, 2012. Amino acids content and electrophoretic profile of camel milk casein from different camel breeds in Saudi Arabia. Saudi J. Biol. Sci., 19: 177-183. 